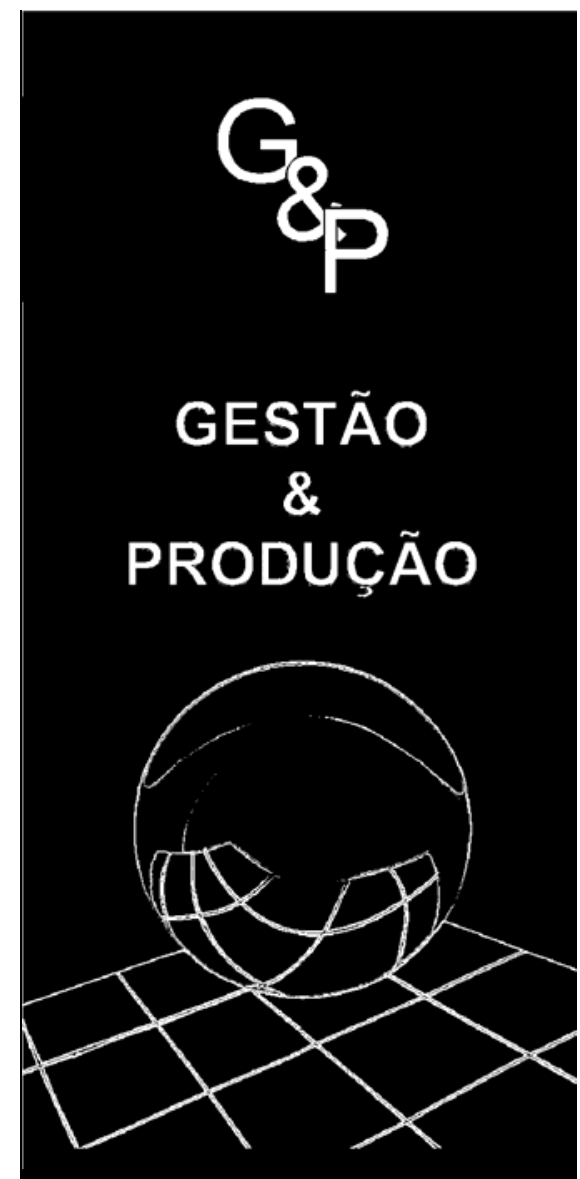

v.3, n.1, p. 8-32, abr. 1996

\section{EMPIRICALLY ASSESSING THE IMPACT OF BUSINESS PROCESS REENGINEERING ON MANUFACTURING FIRMS}

Tor Guimaraes

Tennessee Technological University Cookeville, Tennessee 38501

Wendi Bond

Tennessee Technological University Cookeville, Tennessee 38501

\title{
Abstract
}

While the BPR (Business Process Reengineering) concept is conceptually appealing, in pratice there are many unsuccessful cases. This study aimed to exhaustively identify and rate: the importance of factors proposed as important for successfully implementing BPR projects in organizations; the extent to which various problems and benefits are being encountered; the extent to which proposed BPR objectives are being included in project plans and are actually being derived; and the impact of BPR projects on specific business processes and on the organization as a whole. Several basic hypotheses regarding the BPR implementation process were tested. Last, based on the results, recommendations are made for managers to focus attention and resources on factors important to success, and to proceed in a fashion which minimizes the risk of failure. In general, organizations are not emphasizing some of the most important activies and tasks recommended in the BPR literature, such as changes to customer/market related business processes, the value-added element of every business activity, and others. On the average, the most commonly encountered problems while implementing BPR seem to be very difficult to address in pratice: making business mistakes under pressure to produce quick results, implementation difficulties due to communication barriers between company sub-units, the unexpected size of the required BPR effort, its disruption to business operations, and others. Based on the findings as a whole, it behooves top managers to engage in BPR projects only as a controlled experiment to strategically reposition the organization.

\section{Key-words: reengineering, business processes, manufacturing firms}


1. Introduction

A merica's manufacturing sector accounts for the bulk of corporate research and carries the most weight in the international balance of payments. It remains what has been called "the locomotive that pulls the other sectors of the economy along" (FALTERMAYER, 1993). Regardless of the great importance of U.S. manufacturing, its success or failure is far from assured. In spite of having substantial mechanization and automation, the most productive workers in the world, and greater access to natural resources than perhaps any other nation, U.S. manufacturing has fallen behind (MISKE, 1992). According to a Commerce Department revision in 1992, the value added by manufacturing slipped from 20.7 percent of GNP (Gross National Product) in 1979 to 19.7 percent a decade later. A most distressing result of that recalculation was that the improvement in America's manufacturing productivity in the 1980's is found to be substantially less impressive than advertised earlier: 2.4 percent growth per year on average instead of 3.1 percent (FALTERMAYER, 1993). On the other hand, the American manufacturing sector is thought to be regaining its ability to become more productive (HOWARD, 1994). The erosion of our manufacturing base and the loss of initiative to Japan and Europe have been reversed. From 1982 to 1990, the productivity of U.S. manufacturing workers increased 4.5 percent per year, a record for any period since the end of World War II (HOWARD, 1994). Apparently, in the process of exploring the basic differences between the Japanese and American manufacturing management approaches and applying a host of new methods and techniques, many U.S. firms have been redefining the nature of their businesses (PATTERSON \& HARMEL, 1992).

The main emphasis over the past decade has been on improving quality. Many U.S. Corporations have adopted a new management and operations philosophy widely known as Total Quality Management (TQM). The major underpinnings of TQM are a continuous effort to improve products, processes, and operations to better satisfy customer needs; employee empowerment in decision making and a team approach to identify, prioritize, and change targets for improvement; and a company-wide commitment to TQM strong enough to change what is necessary, including organization values and culture.

The modern view of quality holds that it is not sufficient for product attributes to meet customer requirements; they must exceed them (RAMBERG, 1994). Those American Corporations who have embraced the principles of Total Quality are saying that everybody inside the company should be focused on the customer - not just the marketing department and the sales force; not just those on the production line who now need to understand customer specifications; not just the CEO (Chief Executive Officer) as he visits and spends time with customers. Today everyone, including even staff functions like public relations, should be keenly focused on the company's customers (OLIVER, 1990).

Although there has been a significant amount of success with TQM, companies are now realizing that in many cases there is need for more dramatic improvements in productivity, competitiveness and profitability. This can be accomplished by major paradigm shifts which focus on value-added activities as well as other underpinnings for successfully implementing the concept of

Business Process Reengineering (BPR) (GOLL \& CORDOVANO, 1993; TENG et al., 1994). The results of a 1992 Price Waterhouse survey of the manufacturing industry in the mid-Atlantic region reported that more than 80 percent of the respondents were currently reengineering, in the planning stages or seriously considering it (GOLL \& CORDOVANO, 1993). Another 
survey of over 500 CIOs (Chief Information Officers) given by Deloitte and Touche revealed that the average CIO (Chief Information Officer) is involved in 4.4 reengineering projects up from an average of 1.6 in 1992 (MOAD, 1993).

Essentially, BPR amounts to making radical changes to one or more business processes affecting the whole organization. It also requires a cross-functional effort usually involving innovative applications of technology. Reengineering is a pioneering attempt to change the way work is performed by simultaneously addressing all the aspects of work that impact performance, including the process activities, the people's jobs and their reward system, the organization structure and the roles of process performers and managers, the management system and the underlying corporate culture which holds the beliefs and values that influence everyone's behavior and expectations (CYPRESS, 1994). With BPR, rather than simply eliminating steps or tasks in a process, the value of the whole process itself is questioned (GOTLIEB, 1993).

BPR differs from TQM in two important respects. First, while TQM is focused on continuous improvement, an incremental performance improvement approach, reenginering was founded on the premise that significant corporate performance improvement requires discontinuous improvement - breaking away from the outdated rules and fundamental assumptions that underlie operations. Second, reengineering makes a significant break with previous performance improvement approaches by requiring a high level of state-of-the-art information technology awareness among the entire reengineering team prior to, rather than after, the definition of process changes or improvements (CYPRESS, 1994). Some technologies (i.e. imaging systems and expert systems) can provide substantial opportunities for the redesign of business processes (GUIMARAES, 1993).
As with any other business concept, BPR has stories of both success and failure. According to a Deloitte and Touche survey of over 500 chief information officers, reengineering projects consistently fall short of their expected benefits (MOAD, 1993). At Texas Instruments Inc., where reengineering has been going on for years, they discovered that systems analysts and developers often could not make the adjustment to reengineering quickly enough, and, as a result, some early projects lost momentum and fell as much as 50 percent short of their objectives (MOAD, 1993). On the other hand, reports of successful results from a number of reengineering efforts have been reported recently from Eastman-Kodak Inc., AT\&T, Cigna RE, and Hallmark, among others (TENG, et al; 1994). These companies have reported increases in productivity as well as a reduction in staff after business reengineering. Given these examples of both success and failure, a conclusion can be drawn that the process of implementing BPR must be well thought out and that key factors must be taken into consideration before a company charges forward into a BPR project.

To that effect, this study targeted American manufacturing organizations and had several major objectives. First, it aimed to exhaustively identify and rate: 1) the importance of factors proposed as important for successfully implementing BPR projects in manufacturing firms; 2) the extent to which various problems and benefits are being encountered; 3) the extent to which proposed BPR objectives are being included in project plans and are actually being derived; and 4) the impact of BPR projects on specific business processes and on the organization as a whole. Second, several basic hypotheses regarding the BPR implementation process were tested. Pearson's Correlations were the tests applied. Last, based on the results, recommendations are made for managers to focus attention and resources on factors important to success, and to proceed in a 
fashion which minimizes the risk of failure.

\section{The Theoretical Framework}

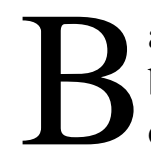

ased on earlier interviews with business managers shepherding their organizations through BPR projects, the basic conceptual model shown in Figure 1 was developed. This intuitive model identifies six major constructs in an organizational view of the BPR implementation process and proposes several relationships among these constructs which are explicitly stated in the section below in the form of hypotheses to be tested.

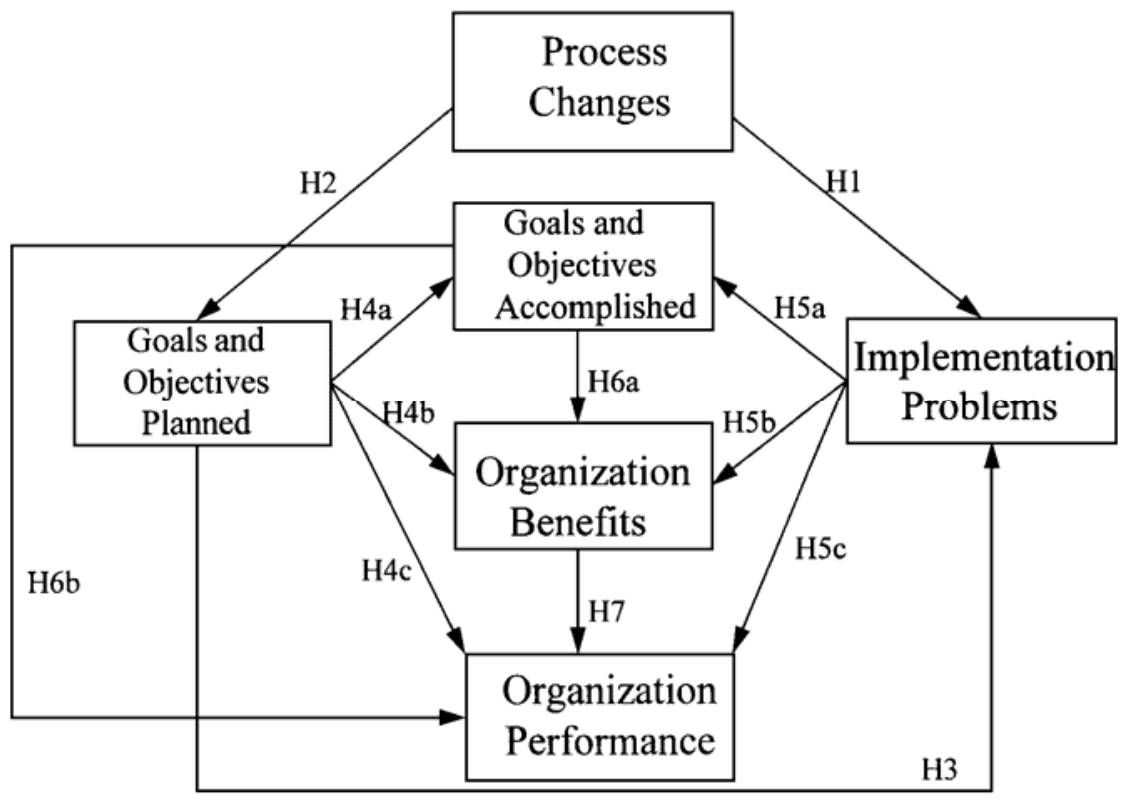

Figure 1: Proposed BPR Implementation Model

\section{The Major Constructs}

\section{Changes to business processes}

BPR projects vary widely in terms of their scope. A project may address anything from one business process to the entire organization and its many processes. A wide variety of business processes are potential targets for reengineering: customer service, sales and order entry, invoicing and billing, purchasing, etc. The list of general business process areas addressed in this study are shown in Table 1.

\begin{tabular}{||l|c|c||}
\hline \hline Table 1: Degree of operational change to business processes & Mean & St. D. \\
\hline \hline 1. Customer service & 2.71 & .85
\end{tabular}




\begin{tabular}{||l|c|c||}
\hline 2. Sales/order entry & 3.50 & .87 \\
\hline 3. Invoicing/billing & 2.80 & .64 \\
\hline 4. Purchasing & 2.92 & .61 \\
\hline 5. Advertising/promotion & 2.78 & .64 \\
\hline 6. Pricing & 2.68 & .96 \\
\hline 7. Marketing research & 2.70 & .81 \\
\hline 8. Product design/development & 3.40 & .95 \\
\hline 9. Distribution & 3.36 & .83 \\
\hline 10.Business planning & 2.76 & 1.03 \\
\hline 11.Inventory management & 3.38 & .88 \\
\hline 12.Quality management & 2.72 & .65 \\
\hline 13.Production scheduling/planning & 3.42 & 1.05 \\
\hline 14.Personnel management & 2.88 & .67 \\
\hline \hline
\end{tabular}

Scale: 1=Not at all, 2=Minor Extent, 3=Moderate Extent, 4=Major Extent, 5=Great Extent

\section{BPR goals and objectives (planned and accomplished)}

The primary objective of BPR is to make business organizations more competitive by improving quality, reducing costs and shortening product development cycles (DAGRES, 1993; GROVER, et al). According to TSANG (1993), BPR's distinguishing characteristics are radical change, cross-functionality, operating across organizational units, breaking outdated paradigms, and involves innovative application of technology. The change process itself should emphasize the valueadded element for every activity, recognizing time as a competitive weapon, focusing on end results and objectives, ensuring quality at the source, planning for an end-to-end solution, challenging the old ways and proposed new ways, using the right technology, empowering people and building consensus on making changes, and setting aggressive goals for the new process (STADLER \& ELLIOTT, 1992). The right idea for BPR is to look at the end-to-end processes that are really important to a company's success, then rapidly redesign who does what and give workers new tools to get more done (MOAD, 1993). It is a new way to think about information technology, in terms of how it supports new or redesigned business processes, rather than business functions or other organizational entities (DAVENPORT \& SHORT, 1990). Based on this literature survey, the goals and objectives addressed in this study were used for two separate constructs: Table 2 shows the extent to which the goals and objectives were included in the BPR project plan; Table 3 indicates the extent to which the goals and objectives were actually accomplished.

\begin{tabular}{||l|c|c||}
\hline \hline $\begin{array}{c}\text { Table 2: Extent to which goals and objectives were included in } \\
\text { BPR project plans }\end{array}$ & Mean & St. D. \\
\hline \hline 1. Increase own competitiveness by improving quality & 2.72 & .65 \\
\hline
\end{tabular}




\begin{tabular}{||l|c|c||}
\hline 2. Increase own competitiveness by reducing costs & 2.78 & 1.01 \\
\hline 3. Increase own competitiveness by shortening product development & 2.63 & .84 \\
\hline 4. Emphasize the value-added element at every activity & 2.62 & .78 \\
\hline 5. Use time as a competitive weapon & 2.59 & .79 \\
\hline 6. Focus on end results and objectives & 2.99 & .74 \\
\hline 7. Apply the right innovative technology & 2.64 & .92 \\
\hline 8. Check quality at its source & 2.83 & .69 \\
\hline 9. Build consensus on making changes & 2.92 & .73 \\
\hline 10.Set aggressive business process goals & 2.65 & .67 \\
\hline $\begin{array}{l}\text { 11.Redesign end-to-end processes important to the company's success } \\
\text { 12.Consider process improvements based on the capabilities of } \\
\text { information technology }\end{array}$ & 2.83 & .66 \\
\hline 13.Reduce costs and production times & 2.69 & .87 \\
\hline 14.Operate across organizational units & 2.79 & 1.03 \\
\hline \hline
\end{tabular}

Scale: 1=Not at all, 2=Minor Extent, 3=Moderate Extent, 4=Major Extent, 5=Great Extent

\section{BPR implementation problems}

While the promises from BPR implementation seem impressive, the potential problems are numerous and vary widely. Although many firms have implemented a variety of reengineering programs over the past years, few have reaped the benefits they expected (CUMMINGS, 1993). According to CSC Index, approximately one fourth of 300 reengineering projects in North America are not meeting their goals and the authors speculated that the figure may be closer to 70 percent (CAFASSO, 1993a). Many CIOs say that the actual benefits of the projects fall short of their expectations along the dimensions of customer service, process timeliness, quality, cost reduction, competitiveness, new/improved technology and sales/revenues (HAYLEY, et al; 1993). At the time the BPR project is announced, stock prices generally increase, only to begin a long slow slide when stockholders realize BPR is not a quick fix (CASCIO, 1993). The up-front costs are high, particularly in the areas of training and consultant fees, with a time consuming learning curve (BOZMAN, 1993). Linking business strategy with IT, implementing and maintaining the technologies required to support the reengineering effort may be extremely difficult for many companies which tend to concentrate on the technology side (BULKELEY, 1992). There is the possibility of redesigning processes that might be obsolete and/or shifted outside to partners in the extended business network (VENKATRAMAN, 1994).

\begin{tabular}{||l|c|c||}
\hline \hline $\begin{array}{c}\text { Table 3: Extent BPR project goals and objectives were } \\
\text { accomplished }\end{array}$ & Mean & St. D. \\
\hline \hline 1. Increased own competitiveness by improving quality & 2.84 & .61 \\
\hline 2. Increased own competitiveness by reducing costs & 2.90 & .75 \\
\hline
\end{tabular}




\begin{tabular}{||l|c|c||}
\hline 3. Increased own competitiveness by shortening product development & 3.05 & .74 \\
\hline 4. Emphasized the value-added element at every activity & 2.81 & .73 \\
\hline 5. Used time as a competitive weapon & 3.11 & .79 \\
\hline 6. Focused on end results and objectives & 3.22 & .84 \\
\hline 7. Applied the right innovative technology & 2.87 & .72 \\
\hline 8. Checked quality at its source & 2.89 & .62 \\
\hline 9. Built consensus on making changes & 3.23 & .88 \\
\hline $\begin{array}{l}\text { 10.Met aggressive business process goals } \\
\text { 11.Redesigned end-to-end processes important to the company's success }\end{array}$ & 2.29 & .82 \\
\hline $\begin{array}{l}\text { 12.The process improvements are based on the capabilities of } \\
\text { information technology }\end{array}$ & 3.13 & .74 \\
\hline 13.Reduced costs and production times & 2.78 & .67 \\
\hline 14.Operating effectively across organizational units & 3.49 & .97 \\
\hline \hline
\end{tabular}

Scale: 1=Not at all, 2=Minor Extent, 3=Moderate Extent, 4=Major Extent, 5=Great Extent

Many companies today pursue such solutions as BPR without understanding future performance level goals. As a result, processes are applied to intangible targets and root causes of business problems are inadequately defined (BELMONTE \& MURRAY, 1993). For some companies, creating an environment in which reengineering will succeed may be exceedingly difficult (GROVER, et al, 1993). Some argue in favor of more gradual departures from traditional practices since managerial innovations take time and induce substantial strain on the organization (BROWN, 1993). As discussed by Guimaraes, Bell \& Marston (1993) in the context of organizational change in general, there is much business organizations can do to reorganize for fast changing environments. The changes often fail because worker habits are not addressed during implementation (GROVER, et al, 1993). Succumbing to the pressure to produce quick results, many managers who implemented BPR tend to ignore the massive changes in organizational structure, have misused and alienated middle managers and lower level employees, sold off solid businesses, neglected important research and development, and hindered the necessary modernization of their plants (CASCIO, 1993). Managers who remain after a downsizing often find themselves working in a different and less friendly environment (CASCIO, 1993).

In cases where BPR resulted in company downsizing, the human resources tend to suffer strong setbacks (EHRBAR, 1993). Unwilling or unable to cope with the changes, many long-time IS workers have left the company (MOAD, 1993). More than half the 1,468 restructured companies surveyed by the Society for Human Resource Management reported that employee productivity either stayed the same or deteriorated after the layoffs. A four-year study of thirty organizations in the automobile industry revealed that very few of the organizations implemented downsizing in a way that improved their effectiveness. Most deteriorated relative to their 'pre-downsizing' levels of quality, productivity, effectiveness, and human relations indicators (CASCIO, 1993). In a 
survey conducted by the New York Citybased American Management Association, the results reveal that fewer than half the companies that have downsized report an increase in profits afterward. According to The Conference Board, also located in New York City, thirty percent of downsized firms found that they ultimately had eliminated the wrong people (GREENGARD, 1993). The loss of expertise is costly to the organization, and replacing lost expertise often is quite expensive (MARGULIS, 1994). Many studies show that following a downsizing, surviving employees become narrow-minded, self-absorbed, and risk averse. That, in turn, results in sinking morale, productivity drops, and distrust of management (CASCIO, 1993). In many cases, massive layoffs of middle managers have led to fewer layers of management but left in place the essence of the same organizational structure (BRANDT, 1993).

Other BPR implementation problems mentioned in the literature include: communications barriers between functional areas (MCKEE, 1992); lack of leadership and inability to properly handle personal risk and confrontations (TADLER, 1992); strategies formed outside the company's ability to implement them (KNORR, 1991); difficulty having the changes accepted by the employees affected (RYAN, 19920; the unexpected enormity of the undertaking and the disruption to the company (HUFF, 1992); the difficulty of balancing the incentives of traditional performance measures against what really needs to be done (FARMER, 1993); some projects falter because nervous corporate backers pull out at the first sign of difficulty (CAFASSO, 1993a); many times it is not clear to business executives whether business reengineering is a practical or worthwhile undertaking (FREISER, 1992); information systems infrastructure in most large organizations today are a major impediment to achieving immediate benefits (BEST, 1992); the elimination of positions and worker anxiety over losing jobs are tough problems (KING, 1993); lack of communication between CIOs and CEOs (MCPARTLIN, 1992); management reluctance to commit resources to the effort while demanding quick results (MCPARTLIN, 1992; Cummings, 1992); major training costs to make the transition, and management frustration with slow results (WEN MANAGER, 1993). Based on the literature, the list of BPR implementation problems considered in this study is shown in Table 4.

\begin{tabular}{|c|c|c|}
\hline Table 4: BPR Implementation Problem Classification \& Rating & Mean & St.D. \\
\hline \multicolumn{3}{|l|}{ PLANNING: } \\
\hline 3. Redesigning processes which are obsolete & 2.58 & .97 \\
\hline 4. Difficult to match best technology with the new process & 3.16 & .73 \\
\hline 5. Focusing on a new technology instead of the business process & 3.07 & .81 \\
\hline 7. Forgetting about employee working habits & 2.76 & .84 \\
\hline 10. Making business mistakes under pressure to produce quick results & 3.81 & .81 \\
\hline Table 4: BPR Problems Classification \& Rating (Continued) & Mean & St. D. \\
\hline 14.Downsizing but keeping the old organization structure & 3.19 & 1.08 \\
\hline 20.Lack of understanding the implementation requirements & 3.35 & 1.11 \\
\hline 22.The BPR process was much larger than anticipated & 3.87 & .91 \\
\hline 26.Conflict between traditional performance measures and BPR goals & 2.78 & .91 \\
\hline 29.Information Systems infrastructure unable to support BPR & 3.34 & 1.03 \\
\hline
\end{tabular}




\begin{tabular}{|c|c|c|}
\hline 30.Long implementation time rendered BPR changes obsolete & 2.87 & 1.05 \\
\hline 32.Top management reluctance to commit funds for BPR & 3.72 & .92 \\
\hline 33. Not enough employee training to implement BPR & 3.06 & .78 \\
\hline 36. Outsiders oversold actual benefits and undersold possible problems & 3.34 & .98 \\
\hline \multicolumn{3}{|l|}{ OPERATIONAL: } \\
\hline 2. Very time consuming learning curve & 3.44 & 1.08 \\
\hline 22.The BPR process was much larger than anticipated & 3.87 & .91 \\
\hline 23.BPR was too disruptive to business operations & 3.81 & .95 \\
\hline 29.Information Systems infrastructure unable to support BPR & 3.34 & 1.03 \\
\hline 30.Long implementation time rendered BPR changes obsolete & 2.87 & 1.05 \\
\hline $\begin{array}{l}\text { 31.Lack of communication between CEO/top management and CIO/IS } \\
\text { manager }\end{array}$ & 3.65 & 1.00 \\
\hline 33.Not enough employee training to implement BPR & 3.06 & .78 \\
\hline \multicolumn{3}{|l|}{ UP-FRONT COSTS: } \\
\hline 1. High up-front costs to get it implemented & 2.67 & .93 \\
\hline 32.Top management reluctance to commit funds for BPR & 3.72 & .92 \\
\hline \multicolumn{3}{|l|}{ SIDE EFFECTS: } \\
\hline 8. Trying to change too much too quickly & 3.37 & .98 \\
\hline 10.Making business mistakes under pressure to produce quick results & 3.81 & .81 \\
\hline 11.BPR process created an unfriendly company environment & 3.77 & .86 \\
\hline 12.Lower employee productivity & 3.19 & .87 \\
\hline 13.Lower employee morale & 2.69 & .87 \\
\hline 15. Outsourcing created many new problems & 3.04 & .91 \\
\hline 18.Resignation of important/productive personnel & 3.14 & .71 \\
\hline 21.Employee high anxiety and resistance to change & 3.44 & 1.17 \\
\hline 25.Too many unpleasant surprises & 3.33 & .95 \\
\hline \multicolumn{3}{|l|}{ ORGANIZATION ENVIRONMENT: } \\
\hline 6. Company environment not conducive to re-engineering & 3.38 & .83 \\
\hline 11.BPR process created an unfriendly company environment & 3.77 & .86 \\
\hline 14.Downsizing but keeping the old organization structure & 3.19 & 1.08 \\
\hline 16.Difficult implementation due to sub-units communication barriers & 3.89 & .83 \\
\hline 19.Lack of leadership to face confrontations \& major business risks & 2.73 & .83 \\
\hline Table 4: BPR Problems Classification \& Rating (Continued) & Mean & St. D. \\
\hline 24.Lack of senior management enthusiasm & 3.36 & .98 \\
\hline 27.Lack of employee consensus to see it through & 3.44 & .98 \\
\hline 28.Lack of management determination to stay on course as problems show & 2.70 & .76 \\
\hline $\begin{array}{l}\text { 31.Lack of communication between CEO/top management and CIO/IS } \\
\text { manager }\end{array}$ & 3.65 & 1.00 \\
\hline
\end{tabular}




\begin{tabular}{|c|c|c|}
\hline 34.Employees "this too shall pass" attitude & 2.87 & .82 \\
\hline \multicolumn{3}{|l|}{ LACK OF RESULTS: } \\
\hline 9. Company stock prices: quick jump and a long slide & 2.41 & 1.03 \\
\hline 12.Lower employee productivity & 3.19 & .87 \\
\hline 13.Lower employee morale & 2.69 & .87 \\
\hline 17.Project fell short of expected benefits & 3.76 & .83 \\
\hline 35. Management frustration with slow bottom line results & 3.44 & 1.00 \\
\hline 36. Outsiders oversold actual benefits and undersold possible problems & 3.34 & .98 \\
\hline
\end{tabular}

Scale: 1=Not at all, 2=Minor Extent, 3=Moderate Extent, 4=Large Extent, 5=Great Extent

\section{Derived benefits}

While the definition for BPR in specific cases is sometimes stretched beyond its commonly accepted features discussed earlier, many organizations have reported significant benefits from their BPR experience (CAFASSO, 1993b). In the case of Pennsylvania Steel Technologies (PST), a subsidiary of Bethlehem Steel Corporation, located in Steelton, Pennsylvania, reengineering projects have banished the substantial overtime expenses associated with certain jobs as well as reduced the input of daily operations from three steps to one step (BENNETT, 1994). Some authors have reported major improvements in customer satisfaction, productivity and profitability at companies that have undertaken reengineering projects (THE ECONOMIST, 1993; GOLL \& CORDOVANO, 1993).

The expected improvements vary dramatically by company: productivity, quality, profits and customer satisfaction are expected to improve from 7 percent to 100 percent, depending on where the company is starting from and the extent of its efforts. Improvements forecast in costs, inventory, cycle time and response time range from 10 percent to as much as 400 percent. Other goals were given as 100 percent on-time deliveries and zero loss of market share (GOLL \& CORDOVANO, 1993). When creatively applied the new processes (in this case implementing focused factories and manufacturing cells) result in dramatic improvements. Other benefits include: reduced floor space requirements; reduced labor requirements, particularly indirect labor; reduced material handling; improved employee empowerment and morale; improved communications between operations; and improved quality (FARMER, 1993). BPR requires teams of people to implement new procedures and programs. These also help improve relationships with customers and suppliers, empower employees, and improve products and processes (GULDEN \& RECK, 1992). Reengineering by restructuring sales teams by product and industry are useful to meet the needs of unique customer groups and to respond more quickly to customer requests (FAIER \& SHEN, 1992).

A poll of IS executives at Computerworld Premier 100 companies found that in nearly half of the organizations reengineering say they are enjoying greater productivity, lower expenses, higher profitability or other benefits (CAFASSO, 1993a). According to Cummings (1993), the highest realized benefits are for improved customer service, faster processes and increased quality, while the lowest improvements are increasing sales and revenue (Cummings, 1993). USAA, a large financial services company, is said to be quite successful at business reengineering, with a program of continuous business process review and redesign which looks at every 
department at least once every two years. One result is that the company is well along the path to becoming a paperless organization (FITZPATRICK, 1992). Other benefits derived from BPR include: major reductions in process cost and execution time, and major improvements in the quality of process outcomes (STADLER \& ELLIOTT, 1992). Based on the literature, the list of BPR benefits addressed in this study are presented in Table 5.

\section{Organization performance}

As discussed earlier, there are many possible business benefits from reengineering. When actually encountered in practice, these benefits hopefully will translate into improved company performance. Therefore, the later should be considered the ultimate measure and dependent variable for studies assessing the overall benefits from substantial reengineering projects. Company performance can be measured in a wide variety of ways (STEERS,1977; VENKATRAMAN \& RAMANUJAM, 1986; SNOW \& HREBNIAK, 1980). Many authors have used one item to measure company performance, such as company profitability (return on total assets) (SNOW \& HREBNIAK, 1980). Given the wide diversity of possible benefits from company innovativeness and the need for content validity, studies assessing the impact of innovation on company performance should use multi-dimensional scales. In this study, the 12 company performance dimensions shown in Table 6, which were previously validated by Gupta \& Govindarajan (1984) have been used to measure the payoffs from company innovativeness.

\begin{tabular}{||l|c|c||}
\hline \hline Table 5: BPR Benefits & Mean & St.D. \\
\hline \hline 1. Machine resources (More efficient use) & 2.73 & .75 \\
\hline 2. Customer satisfaction (Quicker response to customer requests) & 3.55 & .76 \\
\hline 3. Productivity (Decreased cycle time, inventory, or cost) & 3.14 & .77 \\
\hline 4. Profitability (Increased economic growth) & 2.93 & .67 \\
\hline 5. Quality (Improved products/services and related information) & 2.81 & .59 \\
\hline \begin{tabular}{l} 
6. Labor resources (Improved employee morale and productivity) \\
\hline $\begin{array}{l}\text { 7. Sales team (Focused resources to meet needs of unique customer } \\
\text { groups) }\end{array}$
\end{tabular} & 3.46 & .82 \\
\hline $\begin{array}{l}\text { 8. Information technology (Improved to quickly address customer } \\
\text { changes) }\end{array}$ & 2.57 & .95 \\
\hline 9. Sales and marketing processes (More cost-effective) & 2.80 & .74 \\
\hline
\end{tabular}

Scale: 1=Not at all, 2=Minor Extent, 3=Moderate Extent, 4=Major Extent, 5=Great Extent

\begin{tabular}{||l|c|c||}
\hline \hline Table 6: BPR's company impact & Mean & St.D. \\
\hline \hline 1. Sales growth rate & 2.43 & .64 \\
\hline 2. Market share & 2.64 & .71 \\
\hline 3. Operating profits & 2.88 & .94 \\
\hline 4. Rates of profits to sales & 2.59 & .80 \\
\hline 5. Cash flow from operation & 2.84 & .72 \\
\hline 6. Return on investment & 2.67 & .72 \\
\hline
\end{tabular}




\begin{tabular}{||l|c|c||}
\hline 7. New product development & 2.90 & 1.06 \\
\hline 8. New market development & 2.47 & .72 \\
\hline 9. R \& D activities & 2.47 & 1.19 \\
\hline 10.Cost reduction program & 2.97 & .97 \\
\hline 11.Personnel development & 3.02 & .71 \\
\hline 12.Political/public affairs & 2.68 & .80 \\
\hline
\end{tabular}

Scale: 1=Not at all, 2=Minor Extent, 3=Moderate Extent, 4=Major Extent, 5=Great Extent

\section{BPR Success Factors}

The list of success factors identified and rated in this study is shown in Table 7 . This construct has not been proposed as part of the theoretical model proposed and tested here, instead, the success factors are viewed as a collection of individual items whose importance respondents were asked to rate. The literature contains an abundance of personal opinions on what are important factors to BPR success. Some of which sound like self-serving statements, such as the need to bring in specialists for the particular industry. Most of the factors discussed make common sense, such as the need for the BPR project to be driven by customer demand, competitive pressures, and the need to improve financial performance (GOLL \& CORDOVANO, 1993), and/or relationships with suppliers (O'LEARY, 1993). According to BELMONTE \& MURRAY (1993), the first step toward success is recognizing the need for change, and benchmarking against bestin-class companies as a way to reveal the extent of change needed. The need for education and re-education is also widely recognized. Employees must be taught what the reengineering process actually is, how it differs from known work patterns and what role they will play in it (GOLL \& CORDOVANO, 1993). While vision is important to set a direction for a journey, if employees are not involved, the goals will never get accomplished (SHOREY, 1993). Managers are also encouraged to reconsider mechanisms for reward and recognition to keep the reengineered organization moving forward, to instill in people the willingness to share information, and to use hands-on experience in redesigning new processes (GOLL \& CORDOVANO, 1993). Farmer (1993) proposes several important factors: the use of project champions; having an organized and well-disciplined plan of attack; employing a rigorous and detailed analysis process to develop a rough-cut design and identify major issues; avoiding the selection of traditional thinkers as team members; carefully setting up details, tooling, scheduling, maintenance, storage, etc. before implementation; having a defined project organization structure and regularly scheduled meetings of the project manager with every level of this structure to focus attention; using process mapping to distinguish productive activities from those that are non-value-added (CURTIS, et al, 1992); and clearly defining and communicating the mission and vision of the project. In addition, Harrison \& Pratt (1993) suggest that four groups should play a key role in a successful change: The CEO and Senior Executive team who champion the change process and establish the overall goals; the Process Evaluation Teams who construct a vision of the future process and design the improvements; line management who provide resources and implement change; and outside facilitators who help deliver results and challenge the thinking. 


\begin{tabular}{|c|c|c|}
\hline Table 7: BPR Success Factor Classification \& Rating & Mean & St.D. \\
\hline \multicolumn{3}{|l|}{ EXTERNAL: } \\
\hline 1. Use industry specialists and outside assistance & 2.84 & .92 \\
\hline 2. BPR motivated by customer demands and competitive pressures & 3.48 & 1.13 \\
\hline \multicolumn{3}{|l|}{ EMPLOYEE EMPOWERMENT: } \\
\hline 3. Reeducate and retrain workers on what BPR actually is & 3.21 & 1.17 \\
\hline 19.Empower workers so that doers are decision makers & 2.96 & 1.04 \\
\hline \multicolumn{3}{|l|}{ OPERATIONAL: } \\
\hline 4. Use resources effectively & 4.18 & .71 \\
\hline 9. Implement new processes as planned and on schedule & 3.54 & 1.01 \\
\hline 10.Develop a defined project organization & 4.12 & .75 \\
\hline 15.Target only a few critical (though cross-functional) business processes & 3.66 & 1.05 \\
\hline 18.View technology as an enabler, not as a solution & 3.49 & .74 \\
\hline 20. Reduce cost and response times by automation & 3.64 & .97 \\
\hline 21.Desire for continuous performance improvement & 3.18 & 1.14 \\
\hline 26.Adopt an integrated approach to IT and business planning & 3.13 & 1.15 \\
\hline \multicolumn{3}{|l|}{ COMMUNICATION: } \\
\hline 5. Share and exchange information willingly & 4.00 & .84 \\
\hline $\begin{array}{l}\text { 11.Schedule meetings between project manager and each level of project } \\
\text { structure regularly }\end{array}$ & 4.10 & .76 \\
\hline 14.Develop and communicate clear written mission and vision statements & 3.69 & 1.05 \\
\hline $\begin{array}{l}\text { 24.Create an enabling charter that describes the BPR program and support } \\
\text { of management }\end{array}$ & 3.37 & .74 \\
\hline 25.Use surveys to determine what's working and what's not & 3.44 & .81 \\
\hline 26.Adopt an integrated approach to IT and business planning & 3.13 & 1.15 \\
\hline Table 7: BPR Success Factor Classification \& Rating (Continued) & Mean & St.D. \\
\hline \multicolumn{3}{|l|}{ METHODS AND TOOLS: } \\
\hline 6. Utilize hands-on experience in reengineering diverse processes & 3.42 & .81 \\
\hline $\begin{array}{l}\text { 7. Use concept design phase to develop a rough-cut design and to identify } \\
\text { major issues }\end{array}$ & 2.84 & .94 \\
\hline $\begin{array}{l}\text { 8. Determine all setup details, tooling, scheduling, maintenance, storage, } \\
\text { replenishment, quality, etc. before implementation }\end{array}$ & 3.53 & 1.01 \\
\hline $\begin{array}{l}\text { 11.Schedule meetings between project manager and each level of project } \\
\text { structure regularly }\end{array}$ & 4.10 & .76 \\
\hline $\begin{array}{l}\text { 12.Simplify material flow, logistics, planning, and other distinct operations } \\
\text { by using group technology }\end{array}$ & 3.47 & .85 \\
\hline
\end{tabular}




\begin{tabular}{|c|c|c|}
\hline $\begin{array}{l}\text { 13.Use process mapping to distinguish productive activities from non- } \\
\text { value-added activities }\end{array}$ & 2.97 & .86 \\
\hline 15.Target only a few critical (though cross-functional) business processes & 3.66 & 1.05 \\
\hline $\begin{array}{l}\text { 16. Revise procedures that focus on satisfying internal demands rather than } \\
\text { the marketplace }\end{array}$ & 4.21 & .66 \\
\hline 17.Focus on the outcome rather than task & 4.14 & .84 \\
\hline 21.Desire for continuous performance improvement & 3.18 & 1.14 \\
\hline $\begin{array}{l}\text { 24.Create an enabling charter that describes the BPR program and support } \\
\text { of management }\end{array}$ & 3.37 & .74 \\
\hline 25.Use surveys to determine what's working and what's not & 3.44 & .81 \\
\hline 26.Adopt an integrated approach to IT and business planning & 3.13 & 1.15 \\
\hline \multicolumn{3}{|l|}{ LEADERSHIP: } \\
\hline 22.BPR initiated and led from the top-down by senior-level management & 4.24 & .72 \\
\hline $\begin{array}{l}\text { 23.BPR motivated by chief executive willing to be held accountable for } \\
\text { project success }\end{array}$ & 3.97 & .79 \\
\hline
\end{tabular}

Scale: 1=Not Important, 2=Somewhat Important, 3=Moderately Important, 4=Very Important, 5=Extremely Important

GULDEN \& RECK (1992) also have a list of important factors: because reengineering results in large-scale changes to a business process, organizational structures, management systems, and values, executives must carefully target only a few critical (though cross-functional) business processes; they should correct organizational procedures that are focused on satisfying internal demands rather than the marketplace; and focus on outcome rather than task. Other factors which have been proposed are that: the technology be viewed as an enabler, not a solution (HUFF, 1992); let doers be the decision makers (Hammer, 1990); use automation to reduce costs and response times (GREEN, 1992); do not compromise on the need for quality improvements (Faier \& SHEN, 1992; KNORR, 1991); project initiated and led from the top-down by company top management willing to be accountable for project success (KNORR, 1991, \& FREISER, 1992); use surveys to find out what's working and what's not; be completely open about what you're doing, when and why (RASMUS, 1992 \&
MARGOLIS, 1992/93); and adopt an integrated approach to IT and business planning (GROVER et al., 1993).

\section{The Hypotheses Tested}

The need for planning BPR projects has been recognized by many authors (FARMER, 1993; GROVER et al, 1993). As the scope of the BPR process widens to include more business processes, one should expect to see a corresponding increase in implementation problems and in the extent to which goals and objectives are included in the BPR plan, lest changes to some business processes go unaccounted for in the project plans. The absence of this relationship indicates that, on the average, companies are not thoroughly planning their BPR projects. Therefore, we propose:

H1: The extent of changes to business processes is positively related to the extent BPR implementation problems were encountered.

H2: The extent of changes to business processes is positively related to the extent to which important goals and 
objectives were included in the BPR plan.

Several authors (DAGRES, 1993; STADLER \& ELLIOT, 1992)] have discussed important goals and objectives to be included in BPR project plans. Intuitively one would expect that the more thorough the $\mathrm{BPR}$ project plans are, the lower the extent to which implementation problems will occur, the greater the likelihood that projects goals and objectives will be accomplished, that project benefits will be derived, and that the BPR project will have a favorable impact on organization performance. Therefore, we propose:

H3: The extent to which important goals and objectives were included in the BPR plan is inversely related to the extent problems are encountered while implementing BPR.

H4: The extent to which important goals and objectives were included in the BPR plan is positively related to the extent BPR:

H4a: project goals and objectives were accomplished.

H4b: benefits were derived.

H4c: has had an impact on company performance.

Similarly, many authors (BOZMAN, 1993; BULKELEY, 1992; GROVER, ET AL, 1993; CASCIO, 1993; STADLER \&
ELLIOT, 1992) have discussed possible BPR implementation problems and how they may preclude the organization from accomplishing project goals and objectives, expected benefits, and a favorable impact on organization performance. Therefore, we propose:

H5: The extent to which problems were encountered while implementing BPR is inversely related to the extent BPR:

H5a: project goals and objectives were accomplished.

H5b: benefits were derived.

H5c: has had an impact on company performance.

Furthermore, one should expect that if the project goals and objectives are not accomplished, the benefits to the company from the project and its favorable impact on company performance will be reduced. Therefore, we propose:

H6: The extent to which project goals and objectives were accomplished is positively related to the extent BPR:

H6a: benefits were derived, and

H6b: has had an impact on company performance.

H7: The extent to which BPR project benefits were derived is positively related to the extent BPR has had an impact on company performance.

\section{Methodology}

\section{Sampling Method}

The point of entry into the companies participating in this study were through their internal auditing directors/comptrollers (IA's). Questionnaires were mailed to the IA's of 586 randomly selected manufacturing organizations. A total of 152 responses were received within the specified time, however 17 had to be discarded due to missing data (12), invalid responses (2), and responses based on BPR projects which did not meet specified qualifications (3). The usable sample of 135 questionnaires represent a 22 percent response rate which is considered satisfactory for exploratory studies of this type. BPR was defined as 
dramatic changes (paradigm shifts) to business processes, in contrast with incremental improvements. Further, respondents were explicitly asked, unless otherwise indicated, to address the most recent BPR project which has been in operation for at least one year. To protect the respondents, they were promised complete anonymity and that only aggregate information on participants would be made public. A self-addressed, stamped envelope was provided for questionnaire return directly to the author.

\section{Sample Description}

The respondents represent companies at several levels of gross revenue, with few (1.5 percent) having revenues below $\$ 50$ million, and most (74.8 percent) having revenues above $\$ 300$ million.

\section{Construct Measurement}

Respondents rated all items comprising the proposed model's constructs below using the scale 1 (not at all), 2 (to a minor extent), 3 (to a moderate extent), 4 (to a large extent), and 5 (to a great extent). The average rating for the respective sub-items represents the overall measure for each construct.

Changes to business processes: A list of 14 widely known business processes (shown in Table 1) were provided for respondents to rate the degree of operational change to each process.

Planning goals and objectives: Respondents were given a list of 14 desirable goals and objectives (shown in Table 2) for BPR, as proposed in the literature, and asked to rate each in terms of its role in the BPR project plan.

Implementation problems: A list of 36 items (shown in Table 4) proposed in the literature as potential BPR problems was provided to the respondents. They were asked to rate the extent to which each problem had affected the BPR project under consideration.

Goals and objectives accomplished: The same list of items used for rating the extent to which goals and objectives were included in the project plan were used for respondents to rate the extent to which the project goals and objectives were actually accomplished (see Table 3).

Derived benefits: A list of 9 major potential benefits (shown in Table 5) from BPR implementation proposed in the literature were provided for respondents to rate the extent to which each has been derived from the particular reengineering changes.

Impact on organization performance: This was measured along the 12 dimensions proposed by Gupta and Govindarajan (1984) which are shown in Table 6. For each, respondents were asked to rate the impact of the particular BPR project.

\section{Validity of the Measures}

Despite the exploratory nature of this study, several precautions were taken to ensure the validity of the measures used. Many of the recommendations by Carmines and Zeller (1979) were followed. To ensure content validity, a thorough survey of the relevant literature was undertaken to understand the important aspects of each major construct and its components, and not to neglect any important dimension. To further reduce the possibility of non-random error, the main source of invalidity, a group of six practitioners with substantial experience managing major business organization changes, reviewed the questionnaire for validity (measuring the phenomena intended), completeness (including all relevant items), and readability (making it unlikely that subjects will misinterpret a particular question). A few items were added to constructs in the questionnaire and some questions were reworded to improve readability; otherwise, the items composing each major construct remained as derived from the literature.

\section{Reliability of the Measures}

Given the lack of a theoretical basis for the BPR phenomenum, only one of the measures (organization performance) has been previously used and its psychometric properties are relatively well known. The internal consistency reliability coefficients 
(Cronbach's alpha) for the constructs in this study's model are all well above the level of
.50 acceptable for exploratory studies (NUNALLY, 1978).

4. Results

A

s shown in Table 1, on the average, sales/order entry, production/ scheduling planning, and product design/development were the business processes changed to the greatest extent. Surprisingly, given the widespread attention to TQM and the emphasis on customer satisfaction, on the average the customer service process has been changed to a minor extent. On the average, only pricing and marketing research received less attention.

Table 2 indicates that BPR project plans on the average tend to include to the highest extent the goals and objectives of focusing on end results, and building consensus for making changes. On the other hand, on the average companies tend to include to a lesser extent the objectives of using time as a competitive weapon.

Contrary to the opinion of many BPR critics, Table 3 suggests that on the average, companies who have implemented BPR projects have accomplished, at least to a moderate extent, some important project goals and objectives, including: operating effectively across organizational units, built consensus on changes made, and remained focused on end results and objectives. While some of the items show relatively large standard deviations indicating considerable company to company variance around the arithmetic mean, on the average companies are accomplishing all the enumerated goals and objectives somewhere between "to a minor extent” and "to a major extent."

Table 4 shows the ratings of BPR problems classified intuitively into six not mutually exclusive categories: planning, operational, up-front costs, side effects, organization environment, and problem due to lack of results from BPR projects. For exploratory purposes, the reader is encouraged to discover new classification schemes of their own choosing. Based on the classification presented in Table 4, on the average, the most severe planning problems are: discovering that the BPR project is much larger than originally expected, upsetting project plans by making mistakes under pressure to produce quick results, and top management reluctance to commit the necessary funds for the project. Operationally, on the average, the most severe problems are the unanticipated growth of the BPR project, the disruption to company operations, and the lack of communication between the CEO/top management and the CIO/IS manager. The high up-front costs to implement BPR has, on the average, been rated as less than a problem than top management reluctance to commit funds for project implementation. BPR projects seem to produce many problems which may be considered as side effects. The most severe side effects are making business mistakes under pressure to produce quick results, and creating an unfriendly business environment. The most severe problems related to the organization environment are the creation of an unfriendly company environment, difficulty implementing BPR due to communication barriers among organization sub-units, and lack of communication between top management and IS. Last, some BPR problems are due to a basic lack of results. On the average, the two most severe problems in this area are projects falling short on expected benefits and management frustration with slow bottom line results.

\section{Regarding BPR Benefits}

Table 5 shows that, on the average, the greatest benefits from BPR are reported to be quicker response to customer requests (improved customer satisfaction) and improved employee morale and productivity. Improvements in the use of information technology to quickly address customer 
changes, have on the average occurred only to a minor extent. The relatively large standard deviations indicate that individual companies show considerable differences in terms of their BPR derived benefits. Nevertheless, on the average the companies participating in this study are getting all the benefits listed at least to a minor extent.

\section{Regarding BPR Impact on Company Performance}

Based on Table 6, on the average BPR has had less than an impressive impact on company performance. While any improvement in company performance is likely to be important with increased competition in the market place, on the average BPR seems hardly worth the turmoil it often creates within organizations, the employee layoffs often associated with it, and the pressures it often imposes on company personnel. On the average it has helped to a moderate extent the areas of personnel development, cost reduction, new product development, and company operating profits. Again, the relatively large standard deviations tell us that the impact varies considerably from company to company suggesting that its implementation can be quite risky depending on company, application, and project management circumstances.

\section{Regarding BPR Success Factors}

As shown in Table 7, the success factors have been arbitrarily classified by the author into six not mutually exclusive categories: external, employee empowerment, operational, communication, methods and tools, and leadership factors. Readers are encouraged to develop their own classifications for further analysis. With hindsight, having the BPR project motivated by customer demand and competitive pressure, on the average, is considered to be much more important for project success than the use of industry specialists or other outsiders. Similarly, reeducating and retraining workers on what BPR actually is, is deemed more important than empowering the workers performing the required tasks as decision makers. In terms of operational factors, developing a defined project organization and using resources effectively are considered to be very important. The relatively lower standard deviations for these two items indicate that individual respondents are in closer agreement on their ratings. In the communication area, scheduling regular meetings for project managers and each level of the project structure, and sharing and exchanging information willingly (the primary reason for having such meetings) are deemed very important. Methods and tools considered to be very important are the revision of procedures that focus on internal demands rather than the marketplace, a BPR project focus on outcomes rather than tasks, and regular meetings between project managers and all levels of the project organization. Both items under Leadership were considered to be very important on the average.

\section{Regarding Hypothesis Testing}

Based on the major variables intercorrelation matrix shown in Table 8, the model proposed in this study is revised in Figure 2 to graphically show the correlation coefficients for the accepted hypotheses. The following hypotheses were corroborated at the .01 significance level or better:

H1: The extent of changes to business processes is positively related to the extent of BPR implementation problems.

H2: The extent of changes to business processes is positively related to the extent important goals and objectives were included in the BPR project plan.

H4c: The extent to which important goals and objectives were included in the project plan is positively related to the extent BPR has had a favorable impact on company performance.

H5a: The extent to which problems were encountered while implementing BPR is inversely related to the 
extent project goals and objectives were accomplished.

H5b: The extent to which problems were encountered while implementing BPR is inversely related to the extent BPR benefits were derived.

H5c: The extent to which problems were encountered while implementing BPR is inversely related to the extent BPR has had an impact on company performance.

H6a: The extent to which project goals and objectives were accomplished is positively related to the extent BPR benefits were derived.

H6b: The extent to which project goals and objectives were accomplished is positively related to the extent BPR has had an impact on company performance.

H7: The extent to which BPR project benefits were derived is positively related to the extent BPR has had an impact on company performance.

The following hypothesis has been corroborated at the .05 significance level or better:

H4a: The extent to which important goals and objectives were included in the BPR plan is positively related to the extent to which the BPR project goals and objectives were accomplished.

The following hypotheses have not been corroborated:

H3: The extent to which important goals and objectives were included in the BPR plan is inversely related to the extent problems were encountered while implementing BPR.

H4b: The extent to which important goals and objectives were included in the BPR plan is positively related to the extent BPR benefits were derived.

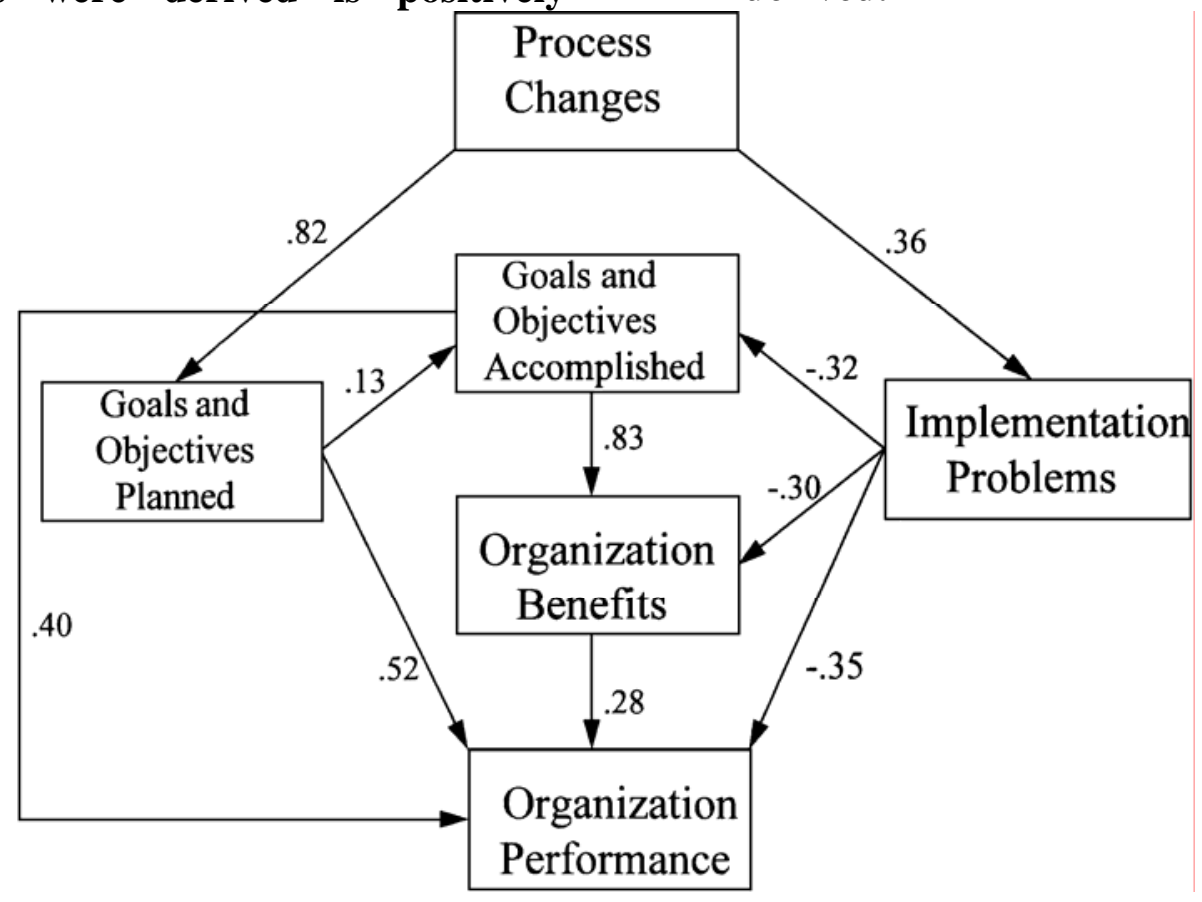

Figure 2: Empirical BPR Implementation Model 


\begin{tabular}{||l|c|c|c|c|c|c|c||}
\hline \hline Table 8: Matrix of Major Variable Intercorrelations (n=324) \\
\hline \hline Variables & Mean & St.D. & 1) & 2) & 3) & 4) & 5) \\
\hline 1. Business Process Changes & & 0.41 & 1.00 & & & & \\
\hline 2. BPR Problems & 3.23 & 0.41 & $.35^{* *}$ & 1.00 & & & \\
\hline 3. Goals/Objectives Planned & 2.75 & 0.46 & $.82^{* *}$ & NS & 1.00 & & \\
\hline $\begin{array}{l}\text { 4. Goals/Objectives } \\
\text { Accomplished }\end{array}$ & 2.98 & 0.36 & NS & $.41^{* *}$ & $.11^{*}$ & 1.00 & \\
\hline $\begin{array}{l}\text { 5. BPR Benefits } \\
\text { 6. Impact on Company } \\
\text { Performance }\end{array}$ & 3.04 & 0.40 & NS & $.42^{* *}$ & NS & $.83^{* *}$ & 1.00 \\
\hline \hline
\end{tabular}

* $\quad \mathrm{P}<0.05$

** $\mathrm{P}<0.01$

NS Not Significant

\section{Conclusions, Implications And Recommendations}

$\mathrm{B}$ ased on the results, one is led to the conclusion that organizations are not emphasizing some of the most important activities and tasks recommended in the literature as basic underpinnings for BPR, such as using time as a competitive weapon, changes to customer/market related business processes, the value-added element of every business activity, and applying the right innovative technology. Therefore, one may surmise that therein lies a major reason why many of the BPR project goals and objectives have been only modestly accomplished.

On the average, the most commonly encountered problems while implementing BPR seem to be rather basic and quite difficult to address in practice: implementation difficulties due to communication barriers between company sub-units, the unexpected size of the required BPR effort, its disruption to business operations, failure to get the expected benefits, making business mistakes under pressure to produce quick results, and reluctance of top managers to commit the funds necessary for the project. Given that most BPR projects benefit from innovative uses of Information Systems technology
(HAMMER \& CHAMPY, 1993), another organizational problem likely to condemn BPR projects to failure within a particular company is the lack of communication between CEO/top managers and CIO/IS managers. While many individual organizations have reported major benefits and significant favorable impact on organization performance, on the average, benefits and company impact from BPR seem rather disappointing compared against all the problems it seems to encounter and generate. Thus, in general, before embarking on a BPR adventure, executives should ensure that at least some of the success factors deemed very important by the respondents are present: the project is initiated and led from the top down by senior level managers; the project will address the need to revise or eliminate procedures satisfying internal demands instead of the company's markets/customers; the project team will develop a defined project organization and will use project resources effectively, as well as will focus on outcomes rather than tasks and will have regularly scheduled meetings between the project manager and each level of the project structure. Also, the 
project manager will cultivate an environment where BPR project team members are likely to share and exchange information willingly. While on the average only these success factors have received the highest importance ratings, other factors with lower ratings but large standard deviations should be further considered in specific situations since at least some of the respondents perceive them as very or extremely important.

Rejecting the hypothesis proposing an inverse relationship between the extent to which goals and objectives were included in the BPR plan and the extent to which implementation problems were encountered suggests that regardless of how comprehensive the planning was, problems will occur. That, in turn, may be due to poor planning or too many surprises which were not possible to plan ahead for. Alternatively, one may surmise that expanding BPR plans to include a wider collection of important goals and objectives is an indication of project complexity, thus without planning, the intensity and variety of the problems would increase. On the other side of the same coin, rejecting the hypothesis that the extent to which goals and benefits were included in the plan is positively related to the extent benefits were derived from the BPR project confirms that, on the average, BPR planning has been ineffective, either due to poor planning or because of surprises during the implementation stages.

Accepting the first two hypotheses suggests that on the average companies broadening the scope of their BPR projects will face greater intensity and/or a wider variety of implementation problems, even though they tend to expand BPR project plans to account for the greater extent of process changes. It is interesting to note that while increasing the extent of BPR planning has no relationship to accomplishing project objectives or deriving benefits from the exercise, it does have a direct relationship to company performance. A possible interpretation for this finding is that in reality the cause/effect relationship is the reverse of what has been proposed. In other words, companies which were able to improve their business performance are also capable of more effective BPR planning.

The extent to which BPR goals and objectives are accomplished is strongly related to the benefits the organization derives from the BPR project, and also related to the extent the BPR project has an impact on company performance. The extent to which benefits are derived is also positively related to company performance. On the other hand, the number and/or intensity of the problems encountered during BPR implementation is inversely related to the extent to which project goals/objectives were accomplished, the derived company benefits from the project, and its favorable impact on company performance. Given that, on the average, project planning does not seem to be a good insurance policy for success, managers should also attempt to develop their companies ability to effectively manage unpleasant surprises (implementation problems). Implementing the basic philosophy, tenets, mechanisms, methods and tools for organizational learning seem to be a major requirement for effectively managing the dramatic organization changes called for BPR and the many resulting surprises.

In direct contradiction with one of the major tenets of organizational learning and TQM, results from this study show that reeducating and retraining workers on what BPR actually is, on the average, was deemed more important in practice than empowering as decision makers the workers performing the required tasks. A likely explanation for this apparent contradiction is that, as discussed earlier, while working on the BPR project under the time pressure, workers will have no time for learning the skills necessary to assume decision making responsibilities.

Based on the findings as a whole, it behooves top managers not to engage in 
BPR projects unless absolutely necessary or as a controlled experiment to strategically reposition the organization. Otherwise, before jumping on the BPR bandwagon, top managers should lead a crusade to improve organizational learning capability by: reducing bureaucracy, shortening communication channels, empowering doers with the authority and responsibility for decision making, emphasizing continuous improvement, team building, competitive intelligence, and employee commitment to the organization.

While this study's major objectives were accomplished, it has some limitations which should be viewed as opportunities for future research. The absence of any established BPR theory capable of producing results useful for business practice has led to a model based on newly developed constructs. Even though the measures used were considered valid by the practitioners testpiloting the questionnaire, and their internal reliability were found to be satisfactory, further statistical analysis should be undertaken to identify sub-constructs and assess their reliability. Further, there is need for focused longitudinal studies to further explore the cause and effect relationships between variables. For example, one important question deals with whether broader and/or more extensive BPR planning leads to a more favorable BPR impact on company performance, or are companies with stronger business performance just better BPR planners? Last, a larger sample size is needed for multivariate statistical analysis to explore possible mediating and moderating effects among the independent variables. While this study has not addressed many important questions, it makes a significant contribution as a first attempt at empirically testing many of the scattered opinions and single-case evidence about BPR in the literature.

\section{Acknowledgement:}

The authors are grateful to the many business managers who contributed their time and experience, and to Nancy Allen, Anita Farley, Valerie Knese Guimaraes,
Kathryn Langley, Van Malone, Paula Snyder, and Myra Yancey for their assistance with this project.

\section{References:}

BELMONTE, R.W. \& MURRAY, R.J.: "Getting Ready for Strategic Change”. Information Systems Management, Vol. 10, No. 3, p. 23-29, Summer 1993.

BENNETT, L.: “Bethlehem Steel Goes High Tech”. IDSystems, p. 18-25, December 1994.

BEST, L.J. \& FORMAN, F.L.: “A Dual Approach”. CIO, The Magazine for Information Executives, p. 28-29, November 15, 1992.

BOZMAN, J.S.: "Downsizing, Rightsizing, Somethingsizing”. ComputerWorld, p.6-10, December 28, 1992 - January 4, 1993.

BRANDT, R.; BYRNE, J.A.; PORT, O.: "The Virtual Corporation”. Business Week, p. 99-102, February 8, 1993.
BROWN, W.B.: "Leading the Way to Faster New Product Development". Academy of Management Executive”, Vol. 7, No. 1, p. 36-47, 1993.

BULKELEY, D.: “Anderson Reengineers Big Business”. Systems Integration Business, p. 2227, August 1992.

CAFASSO, R.: "Rethinking Reengineering". ComputerWorld, p. 102-105, March 15, 1993 a.

CAFASSO, R.: “Jean Genies”. ComputerWorld, p. 99-102, June 14, 1993b.

CARMINES, E.G. \& ZELLER, R.A.: "Reliability and Validity Assessment”. Sage University Paper, 1979.

CASCIO, W. F.: "Downsizing: What do we know? What have we learned?". Academy of Management Executive, Vol. 7, No. 1, p. 95-104, 1993. 
CUMMINGS, J.: "Reengineering is high on list, but little understood Management Strategies". Network World, July 27, p.27, 1992.

CUMMINGS, J.: "Reengineering Falls Short of Expectations, Study Finds". Network World, p.27, March 22, 1993.

CURTIS, B.; KELLNER, M.I.; OVER, J.: "Process Modeling". Communications of the ACM, p. 75-90, September 1992.

CYPRESS, H.L.: "Reengineering”. OR/MS Today, Vol.21, No. 1, p. 18-29, February 1994.

DAGRES, T.: "Network Reengineering for Competitive Advantage”. White Paper, 1993.

DAVENPORT, T.H. \& SHORT, J.E.: "The New Industrial Engineering: Information Technology and Business Process Redesign”. Sloan Management Review, Vol. 31, No. 4, p.11-27, Summer 1990.

EHRBAR, A.: "Reengineering Gives Firms New Efficiency, Workers the Pink Slip”. The Wall Street Journal, Vol. CCXXI, No. 51, March 16, 1993.

FAIER, J. \& SHEN, D.: “A telecom game plan for the 1990s”. Telephony, p.31-37, October 19, 1992.

FALTERMAYER, E.: "Invest or Die". Fortune, p. 42-52, February 22, 1993.

FARMER, J.R.: “Reengineering the Factory'. APICS, p. 38-42, March 1993.

FITZPATRICK, E.W.: "Information Management”. Journal of the American Society of CLU and ChFc, p. 34-35, September, 1992.

FREISER, T. J.: "The Right Start for Business Reengineering”. Information Strategy: The Executive's Journal, p. 26-30, Fall 1992.

GOLL, E.O. \& CORDOVANO, M.F.: "Construction Time Again”. CIO, The Magazine for Information Executives, p. 32-36, October 15, 1993.

GOTLIEB, L.: “Information Technology”. CMA Magazine, Vol. 67, No. 2, p. 9-10, March 1993.

GREEN, C.: "Quality Improvement--From Dreams to Reality”. Canadian Business Review, p. 33-37, Autumn 1992.

GREENGARD, S.: “Don't Rush Downsizing: Plan, Plan, Plan”. Personnel Journal, 72(11), p. 64-76, November 1993.

GROVER, V.; TENG, J.T.C.; FIEDLER, K.D.: "Information Technology Enabled Business Process Redesign: An Integrated Planning Framework”. OMEGA, Vol. 21, No. 4, p. 433447, 1993.

GUIMARAES, T.: “Managing Expert Systems Technology and Business Process Reengineering”. In: Symposium of the Information Processing Society of Japan, Tokyo, Japan, June 19, 1993.
GUIMARAES, T.; BELL, R.; MARSTON, R.: "Organizing for Innovation". 4th International Forum on Technology Management, Berlin, Germany, October 18-20, 1993.

GULDEN, G.K. \& RECK, R.H.: "Combining Quality and Reengineering Efforts for Process Excellence". Information Strategy: The Executive's Journal, Spring, p. 10-16, 1992.

GUPTA, A.K. \& GOVINDARAJAN, V.: "Business Unit Strategy, Managerial Characteristics, and Business Unit Effectiveness at Strategy Implementation”. Academy of Management Journal, Vol.27, No. 11, p. 25-41, 1984.

HAMMER, M. \& CHAMPY, J.: "Explosive Thinking”. ComputerWorld, p. 123-125, May 3, 1993.

HAMMER, M.: “Reengineering Work: Don't Automate, Obliterate”. Harvard Business Review, p. 104-112, July-August 1990.

HARRISON, B. \& PRATT, M.: "Transforming the Enterprise”. Canadian Business Review, 20(2), p. 22-25, Summer 1993.

HAYLEY, K.; PLEWA, J.; WATTS, M.: "Reengineering Tops CIO Menu”. Datamation, p. 73-74, April 15, 1993.

HOWARD, J.S.: "Reinventing the Manufacturing Company”. D\&B Reports, p. 18-21, January/February 1994.

HUFF, S.L.: "Reengineering the Business". Business Quarterly, p. 38-42, Winter 1992.

KING, J.: "Reengineering Repercussions". ComputerWorld, p. 149-150, June 28, 1993.

KNORR, R.O.: "Business Process Redesign: Key to Competitiveness". The Journal of Business Strategy, p. 48-51, November/December 1991.

MARGOLIS, N.: "Voices of Experience". ComputerWorld, p. 16-17, December 28, 1992/January 4, 1993.

MARGULIS, S.T.: "Bad News, Good News about Downsizing”. Managing Office Technology, 39(4), p. 23-24, April 1994.

MCKEE, D.: “An Organizational Learning Approach to Product Innovation”. Journal of Product Innovation Management, Vol. 9, p. 232245, September 1992.

MCPARTLIN, J.P.: "Seeing Eye to Eye on Reengineering”. Information Week, p. 74, June 15, 1992.

MISKE, J.C.: "Reversing the Decline of Manufacturing in America”. Foundry Management \& Technology, p. 17, September 1992.

MOAD, J.: "Does Reengineering Really Work". Datamation, p. 22-28, August 1, 1993.

NUNALLY, J.C.: Psychometric Theory, Second Edition. McGraw-Hill, New York, NY, 1978. 
O'LEARY, M.: “A New Life for Purchasing”. CIO, The Magazine for Information Executives, p. 3241, May 1, 1993.

OLIVER, W.H.: “The Quality Revolution”. Vital Speeches of the Day, p. 625-628, 1990.

MANAGER, O.: "Making the Case for Change". Owen Manager, p. 17-19, Spring 1993.

PATTERSON, M.C. \& HARMEL, R.M.: "The Revolution Occurring in American Manufacturing”. IM (for Industrial Management), p. 15-17, January/February 1992.

RAMBERG, J.S.: “TQM: Thought Revolution or Trojan Horse?”. OR/MS Today, Vol. 2, No. 4, p. 18-24, August 1994.

RASMUS, D.: “'Reengineering or Evolution Through Violent Overthrow”. Manufacturing Systems, Vol. 10, No. 9, p. 52-58 , September 1992.

RYAN, H.W.: “Managing Change”. Information Systems Management, p. 60-62, Summer 1992.

SHOREY, E.: "Process Redesign". Executive Excellence, Vol. 10, No. 10, p. 16-17, October 1993.

SNOW, C.C. \& HREBNIAK, L.: "Strategy, distinctive competence, and organizational performance”. Administrative Science Quarterly, Vol. 25, p.317-335, 1980.
STADLER, D.A. \& ELLIOT, S.A.: "Remake Your Business”. Inform, February, p. 12-17, 1992.

STEERS, R.M.: Organizational Effectiveness: A Behavioral View. The Goodyear series in management and organizations, Santa Monica, CA: Goodyear Publishing, 1977.

TENG, J.T.C.; GROVER, V.; FIEDLER, K.D.: "Business Process Reengineering: Charting a Strategic Path for the Information Age". California_Management Review, Vol. 36, No. 3, p. 9-31, Spring 1994.

THE ECONOMIST: “Take a Clean Sheet of Paper”. The Economist, Vol. 327, p. 67-68, May 11994.

TSANG, E.: "Business Process Reengineering and Why It Requires Business Event Analysis". CASE Trends, p. 8-15, March 1993.

VENKATRAMAN, N.: "IT-Enabled Business Transformation: From Automation to Business Scope Redefinition”. Sloan Management Review, Vol. 35, No. 1, p. 73-87, Winter 1994.

VENKATRAMAN, N. \& RAMANUJAM, V.: "Measurement of Business Performance in Strategy Research: A Comparison of Approaches". Academy of Management Review, Vol. 11, No. 4, p. 801-814, October 1986.

\section{AVALIANDO EMPIRICAMENTE O IMPACTO DA REENGENHARIA DE PROCESSOS EMPRESARIAIS NAS FIRMAS DE MANUFATURA}

\section{Resumo}

Embora o conceito de Reegenharia de Processos Empresariais (BPR) possua um forte apelo conceitual, na prática existem muitos casos que redundaram em fracasso. Este trabalho pretende identificar e medir exaustivamente: a importância dos fatores que pensamos que são importantes para que a implantação nas organizações dos projetos de $B P R$ tenha êxito; a extensão dos problemas e benefícios que têm sido encontrados; em que extensão os objetivos estabelecidos da BPR têm sido incluídos nos planos dos projetos e são realmente atingidos; e o impacto dos projetos de BPR sobre os processos específicos dos negócios e sobre a organização como um todo. Várias hipóteses básicas com respeito ao processo de implantação de BPR foram testados. Por fim, baseadas nos resultados, recomendações são feitas para que os gerentes enfatizem a atenção e a alocação dos recursos nos fatores importantes para o sucesso, e procedam de uma maneira que minimize o risco de falha. Em geral, as organizações não estão dando ênfase a algumas das atividades $e$ tarefas mais importantes recomendadas na literatura a respeito de BPR, tais como, mudanças para processos de negócios relacionados com os clientes/mercado, o elemento valor adicionado de cada atividade da empresa, e outros. Na média, os problemas mais comumente encontrados na implantação de BPR parecem ser muito difíceis de serem abordados na prática: erros são cometidos devido à pressão para se obter resultados rápidos, dificuldades de implantação devido a barreiras de comunicação entre sub-unidades da companhia, o tamanho inesperado do esforço de BPR requerido, sua ruptura para com as operações da empresa, e outros. Baseado nas conclusões tiradas como um todo, convém aos 
altos executivos engajar-se em projetos de BPR apenas como um experimento controlado para reposicionar estrategicamente a organização.

Palavras-chave: reengenharia, processos empresariais, empresas de manufatura 